\title{
Spinocerebellar ataxia type 30
}

INSERM

\section{Source}

INSERM. (1999). Orphanet: an online rare disease and orphan drug data base.

Spinocerebellar ataxia type 30. ORPHA:211017

Spinocerebellar ataxia type 30 (SCA30) is a very rare subtype of autosomal dominant cerebellar ataxia type III (ADCA type III; see this term) characterized by a slowly progressive and relatively pure ataxia. 